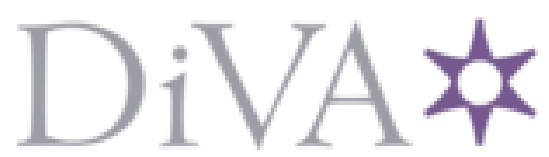

http://www.diva-portal.org

This is the published version of a paper published in Nordic Journal of Religion and Society.

Citation for the original published paper (version of record):

Sporre, K. (2013)

Value conflicts and faith based schools - in contemporary Sweden.

Nordic Journal of Religion and Society, 26(2): 175-191

Access to the published version may require subscription.

N.B. When citing this work, cite the original published paper.

Permanent link to this version:

http://urn.kb.se/resolve?urn=urn:nbn:se:umu:diva-82473 


\section{VALUE CONFLICTS AND FAITH BASED SCHOOLS - IN CONTEMPORARY SWEDEN}

Abstract

This article identifies value conflicts in debate regarding Swedish faith based schools 20102012 explored against the background of a study by Gerle (1999). As the policy changes of the Swedish school system from the 1990s form the preconditions for contemporary faith based schools those changes are outlined. The results show that the value conflicts observed by Gerle can still be noted e.g. the wish to freedom of religion in educating children into one's own religion, as well as the conflict of the right of parents vs. the rights of children in education. A new value conflicts is the ending of school ceremonies of municipal schools in churches and the role of religion in them. Does this mirror a shift in the influence of a Lutheran majority culture? Another surfacing value conflict is whether the making of profit in the school sector is acceptable or not.

Keywords: value conflicts, faith based schools, religious education, marketization, independent schools

\section{Introduction}

Swedish independent schools (Swedish: «friskolor» or «fristående skolor») have increased considerably in numbers since the beginning of the 1990s (Skolverket 2011b). In 2010/2011, 24 per cent of students in upper secondary school, school years 10-12, attended an independent school as compared to one per cent in 1993/94. For compulsory school, school years 1-9, the corresponding figures are twelve per cent in 2010/2011 and around one per cent in 1992/93 (Skolverket 2011b: 81-82). In a European perspective the Swedish development of independent schools stands out as exceptional as Sweden has tripled the number of pupils in the private school sector during 2000-2009 compared to the majority of European countries which have had minor increases during this same period (Eurydice 2012: 32). Of all pupils in the Swedish compulsory school 0.9 per cent attend a faith based school (Skolverket 2011a: 48-51).

The Swedish increase of independent schools has been studied and analyzed from different points of view as a neo-liberal ideological policy shift e.g. towards marketi- 
zation (Lundahl 2002; Arreman and Holm 2011) or world models/globalization (Daun 2008); as raising issues of equal opportunity for pupils e.g. in terms of educational quality (Skolverket 1997) or fairness in evaluation with reference to grades (Vlachos 2010); or regarding forms of ownership of the independent schools (Skolverket 2012a). The fact that Swedish independent schools can be, and often are, organized as profitable companies has been an underlying issue for public debate and criticism, not least since independent schools receive their total income through public funding based on taxes. As this development has formed the organizational framework within which the faith based schools have grown and now operate the Swedish system of independent schools, their background, funding and organization will be somewhat enlightened below.

The specific interest of this article is however the independent Swedish schools which have a religious confessional basis, being Christian, Jewish, or Muslim. Does their faith based status create problems? If so, what kind of problems? More specifically, does that cause value conflicts of some kind? If so, what kind of value conflicts? In 1999, ethicist Elisabeth Gerle (1999) identified value conflicts in relation to Muslim and Christian independent schools and their activities within the Swedish school system. Here Gerle's concept value conflict serves as an analytical tool and the results will be compared with her study.

The years 2010-2012 form the studied time span regarding value conflicts. During these years, a) reports from the two school authorities: the Swedish National Agency for Education (NAE) (Swedish: «Skolverket») and the Swedish School Inspectorate (SI) (Swedish: «Skolinspektionen»), and b) press releases and newspaper articles expressing public debate regarding faith based independent schools will be studied and analyzed, as well as c) policy documents. Through the choice of period, the study gains actuality and the time period becomes limited. In addition, the chosen period coincides with a change of School Act and curriculum which have a significant effect on the studied issues. In a general sense, the issues discussed here relate to issues of religious plurality and freedom of religion, issues that nowadays are raised in a more multi-religious Sweden against the background of a formerly centralized school system. Regarding religious education, it takes place in both the faith based independent schools and all other Swedish schools. Religious education is to be non-confessional and, in plurality, provide an orientation about religions, worldviews, ethics and existential questions. However, the form of this education is not of specific interest here but, as indicated, the value conflicts around the faith based schools.

The article has the following structure: a) Three terminological issues; b) Swedish independent schools - a brief history; c) A summary of Gerle's (1999) study; d) The task, method and studied material clarified; e) Value conflicts in Swedish faith based independent schools; f) Summary and discussion. Initially it should also be noted that the above mentioned Swedish National Agency for Education (NAE) and the Swedish School Inspectorate (SI), the latter since 2008, form the two main actors in the administrative steering, directing and controlling of the activities of the Swedish schools. NAE sets out the goals and guidelines for pre-school and school, supports and evaluates. The responsibility for the organization of schools rests with local municipalities 
or independent schools. The task of SI is to scrutinize, make inspections, and receive complaints, and through its activities secure that the goals are lived up to. SI also assesses applications to run independent schools. For a critical discussion on the role of SI see Rönnberg et al. (2013).

\section{Terminological issues and statistical background}

In a study by NAE (Skolverket 2008) the school sector and its organization is studied comparatively in England, Scotland, Finland, Iceland, the Netherlands, Denmark, Australia and Norway, with special reference to public, private and independent schools. The author notes that terminology and organization represent diversity and historical differences. The terminology often reflects either juridical forms for ownership, responsible authority (Swedish: «huvudman»), or forms of funding (Skolverket 2008: 9). The Swedish use of the term «independent schools» to denote schools with education providers not belonging to the public sector but still being publicly funded is somewhat unusual, noted also by Daun (2008: 739), this as their independence can be questioned. In the report on education from the EU 2012 one can note that the qualifier grant-aided is used when describing Swedish independent schools (Eurydice 2012: 34). Another term would be grant-funded as Swedish independent schools are not allowed to collect fees from parents, and have their income from the state depending on their numbers of pupils. In a Nordic context both the historic background of a private school sector, the contemporary numbers of such schools, and the pedagogicalideological discussion around those school differ, and the Swedish expansion stands out (see Berge and Hyggen 2011; Eurydice 2012).

However, although the Swedish use of the term independent school is somewhat inadequate, here I chose to use the term independent schools (Swedish: «fristående skolor» or «friskolor») referring to: Swedish schools that form part of the formal school system, are publicly funded, and have responsible authorities in the form of foundations, voluntary associations, faith communities, or companies, i.e. education providers that are not municipal authorities/communities. As a rule, the state and communities almost exclusively organized the comprehensive Swedish school, school years 1-9 and 10-12, at the beginning of the 1990s (see Lundahl 2002). Now, as already stated, the numbers of independent schools have increased to the point where they offer education to 24 per cent of all upper secondary pupils and to 12 per cent of pupils in compulsory schools (Swedish: «grundskola»). It thus follows that independent schools are more common at upper secondary level. In general, independent schools have smaller numbers of students than those having a community as their responsible authority. Independent schools also have fewer teachers per student (Skolverket 2011b).

Another term that needs clarification is faith based. The statistics from NAE (Skolverket 2011a) reveal that the number of independent schools during the period 2010/2011 at compulsory school level was 741 out of 3,880. Sixty-six of these 741 were faith based, the others being general pedagogical (626) or influenced by the ped- 
agogy stemming from Rudolf Steiner, so called Walldorf schools (39). These are the three main alternatives for registration of independent schools, in addition to (4) international schools, and (5) national boarding schools (Swedish: «Riksinternat»). The current percentage of pupils in faith based schools is 0.9 per cent of the total number of compulsory school pupils. This means they are the second largest group among independent schools after general pedagogical schools (10.2\%). Walldorf schools, coming third, account for 0.5 per cent of the total number of pupils. In both 1970 and 1990, the corresponding total figures for pupils in independents schools did not reach one per cent, and the noticeable increase in independent schools began in 1993/1994 (Skolverket 2011a: 48-51).

Given these figures regarding the proportion of students in faith based schools as a background, the term faith based in this article refers to a Swedish school that has an education provider (Swedish: «huvudman») which identifies itself as religious. This can often be seen as a reference to a religion in the statutes of the body behind the independent school, via its name, or stated on its website. Thus, the faith based background is claimed by the actors themselves, not least when applying for permission to run an independent school. In this article I will abbreviate faith based independent school to FBIS.

FBISs are not systematically singled out in the general statistics from NAE, and it is somewhat difficult to gather information about them. Facts and figures about them are sometimes mirrored in detail in parts of reports, but then more as a «byproduct» of other matters. This makes presenting an overview more complicated. As a result, when providing background, I will treat the faith based schools as part of the wider development of independent schools, but single them out when the material allows for it. At the same time as the rapid increase in independent upper secondary schools has taken place, meaning that they have tripled in number since 2000/2001 (Skolverket 2011a: $80-84)$, the total number of students has been diminishing in the relevant age groups and will continue to do so until 2016/2017 (Skolverket 2012a: 16). From the administrative point of view, since July 1st 2011 all Swedish schools, whether independent or run by local communities, have to adhere to the steering rules and regulations of the new School Act, Skollagen 2010:800 (Riksdagen 2010).

Another term to be described is value conflict. The use of it here is in line with Gerle's (1999). A value, according to her, represents an ideal expressing an aspect of «the good life», e.g. societal cohesion, loyalty, freedom, or community fellowship. Values are further related to views held regarding ontology (Swedish: «verklighetsuppfattning»), the human being (Swedish: «människosyn»), political issues and religious beliefs. Values are also related to traditions, and can vary within them, and thus express diversity within traditions. Values are also changing over time (Gerle 1999: 27-30).

\section{Swedish independent schools - a brief history}

Several of the studied articles and reports go back to 1991/92 when the political changes came that paved the way for the increase in the number of Swedish independ- 
ent schools (Arreman and Holm 2011; Skolverket 2012a). However, one of the reports (Skolverket 1997) briefly details the history of twelve schools going back beyond the 1990s. Three of these schools are faith based, one Jewish and two Christian, and were founded in 1955, 1967 and 1971 respectively. Four studied Muslim schools and four language based schools were founded during the 1990s. Out of the twelve schools in the study, the Estonian school in Stockholm is the oldest one, having been founded in 1945. This demonstrates that independent schools existed before 1991/1992, albeit not with the same funding conditions - the present voucher system with pay to schools per pupil was introduced during the 1990s. In the quoted report (Skolverket 1997), the main concern raised is the problem that independent schools may recruit from a selected part of the population and so be able to contribute to segregation, by keeping the school-children attending apart from others. An additional concern deals with the problem that certain independent, here Muslim, schools may recruit from limited groups of immigrants where the educational level among parents is low, as is the degree of integration into Swedish society, and the socio-economic situation of the family can be highly strained, with the result that the independent school might contribute to societal exclusion and an inadequate education for the students attending. The main concern in the conclusion is some independent schools' ability to provide education of a high enough quality, including issues of leadership and organization where problems were noted.

Arreman and Holm (2011) and Lundahl (2002) study the policy changes of the 1990s that brought about the conditions for the change towards an increase in independent schools; Lundahl (2002) by also analyzing the development in relation to the earlier Swedish school system and the overall societal development. She then notes how during the 1990s the state's former central (economic) control of education was handed over to municipalities, and the voucher system for the funding of each pupil's education was introduced, whereby the role of the state was reduced to steering by formulating objectives for education. By paving the way for independent schools, individual freedom of choice of school and education was stressed and promoted for parents/ pupils (Lundahl 2002: 691).

The effects of these changes have been studied by various researchers regarding different systemic aspects. One of these is the overall short-term and long-term effects on the grades of a school system when competition between schools is part of the system. Can grades 'distribute' pupils fairly to higher education, and is there a benefit from competition (Böhlmark and Lindahl 2008)? Another study addresses the consequences of competition regarding teachers' grading of individual pupils. Is grade inflation occurring, whereby certain pupils, or groups of pupils, in certain schools receive more favorable grades (Vlachos 2010)? Recent reports from NAE also form part of a more critical evaluation of the changes, where issues of equal opportunity in relation to education for children and young people are evaluated e.g. in relation to issues such as regional and local opportunities for the provision of resources (Skolverket 2012b). Another report, Enskilda huvudmän och skolmarknadens ägarstrukturer (Independent education providers and the owner structures of the school market) (Skolverket 2012a), discusses in detail the structure of the responsible authorities behind the independent 
schools. The report reveals a pattern in which the majority of the education providers are companies and minority associations, foundations, or other forms of organization. The report provides valid and varied information regarding the ownership of independent schools during the period 2005-2009, and provides a basis for critical discussion. The FBISs are not singled out in the report, meaning that their proportion of companies, foundations, etc. is not described. However, a brief study of websites reveals that they are to be found in all categories of organizational patterns, and as companies, e.g. Svenska kyrkan i Fagersta AB (Church of Sweden in Fagersta Ltd), Fagersta being a town in the south of Sweden.

In NAE's annual report from 2011 (Skolverket 2011a, 2011b) a section in part two addresses the increased marketization of the Swedish school sector (Swedish «Ökat marknadsinslag i skolsektorn») (Skolverket 2011b: 79-90). In the introductory part of the report, it is stated that the diversity of the Swedish school sector today is considerable, and that there are independent schools with non-profit interests as well as those with profit interests. Further, there are schools struggling to keep their numbers up and those having to say no to applicants. There are education providers that own just one school, while other schools are owned by a business group (Skolverket 2011b: 12, 7990). The special report on ownership structures in independent schools gives more detailed information and describes some of the business groups, some being large and international, and others being smaller (Skolverket 2012a). Further, in July 2011, the Swedish government issued instructions for a committee to investigate means and procedures for NAE and SI when e.g. too much profit is taken out of an independent school risking the quality of the education (Regeringen 2011). This committee was due to finish its work during the autumn 2012 but their time was extended four times until May 31, 2013.

\section{Gerle's study - value conflicts at the turn of the $21^{\text {st }}$ century}

In 1999, Elisabeth Gerle presented her study (Gerle 1999) regarding value conflicts in the debates on Swedish Muslim and Christian independent schools. The study formed part of a larger research project «Value traditions, value communities and value conflicts in Swedish cultural heritage and contemporary society» undertaken during the years 1995-2000 at Lund University, Sweden. Gerle's study bore the title Multiculturalism - for whom? The debate on Muslim and Christian independent schools reveals value conflicts in Swedish society (Gerle 1999, my translation).

In Gerle's analysis and discussion of value conflicts, she places them within the changing context of modernity, and Sweden is described as a country undergoing change from a culturally homogenous society to a more multicultural one. When analyzing the value conflicts in the debate on independent schools Gerle draws on the work of a number of academic scholars, one of them being Seyla Benhabib. In Benhabib's work, Gerle finds the basis for her analysis and discussion of cultures as changing, and gender, citizenship and issues of power, placed in relation to minority and majority issues. 
At the time of Gerle's study, in 1998, 298 independent schools were operating with 31,000 pupils attending them, totaling three per cent of all Swedish pupils. 60 per cent of all independent schools worked in the sector of forms 1-9 and 40 per cent in the upper secondary school sector. 7,000 pupils attended schools with a faith based or language/ethnicity profile (Gerle chose to include schools with a language/ethnicity profile as schools for Muslim children sometimes described themselves as providing Arabic language and not religion). The majority of the FBISs had a Christian profile. One of the presuppositions Gerle states for her study is that value conflicts do not always follow along the lines of religious groups, but instead cut across supposedly homogenous religious value communities and further that cultures are in states of constant change. Issues of autonomy for both individuals and groups are raised in the study. Gerle warns against overly easy dichotomies. For the comparison with her study, I will now summarize and briefly describe five value conflicts surfacing in her work.

\section{Freedom of religion - in school}

Among certain Muslim and Christian groups there exists a will to express issues of faith, and faith based ethics with their moral norms, in school. This is in contrast to a Swedish majority culture expressing a secular rationality based on social engineering combined with a historical Christian Lutheran heritage, expressed in the ambitions of fostering democratic citizens. This majority culture is taken for granted as fundamental to schools.

\section{Critical thinking - religious truth and authority}

In the curriculum for Swedish schools, the development of a critical individual understanding is crucial in terms of the knowledge/learning the pupil is to gain. This can come into conflict with a religious understanding of truth within Muslim or Christian contexts in combination with the view of assigning authority to religious leaders and parents - and not to pupils.

\section{Whose rights - those of parents or children?}

The curriculum stresses the perspective of the rights of children to develop knowledge relevant to themselves, i.e. knowledge that is instrumental to their own development. This can clash with an emphasis of the rights of the parents and the community to foster children/young people into the tradition.

\section{Individual choice and group/community decision-making - and gender equality}

The curriculum further emphasizes the equality between boys and girls and the individual freedom of pupils to be educated independently of traditional gender roles, and also to study towards an occupation independently of traditional ways of viewing careers. This emphasis on gender equality may clash with traditional gender roles expressed in religions where the sexes are viewed as different and complementary to one another, implying that boys and girls are to be separated in certain school activities 
like sports and education about sexuality and social relationships, as well as generally prepare for different occupational roles.

\section{Underlying value conflict - critical citizens versus devoted religious believers}

It could be said that there is an underlying value conflict: the democratic fostering of equal citizens irrespective of gender, together with a critical individual formation of knowers as expressed in the curriculum. This can clash with the fostering for a religious community, not least when it views certain value issues described above differently.

\section{Task, method, material clarified}

The question of this article is: What value conflicts can be identified regarding faith based independent Swedish schools in public debate and in material from NAE and SI during 2010-2012? The method used is content analysis of texts where ethical aspects are highlighted given the focus on value conflicts. From a methodological point of view, this means that principled ethical theoretical arguments are favored in the analysis against the background of research based statistical data, policy analysis and educational sociological perspectives; as well as ideological, pedagogical or economic views expressed in media, reports and other material. The material primarily analyzed in the study is press releases and newspaper articles; and reports, evaluations and inspection reports from NAE and SI, as well as policy texts, including juridical documents, form a background. As already stated, the time period is 2010 until July 2012. The chosen approach of studying principled arguments is reminiscent of a study by Jackson (2003); however, the context here is a different one, and this study has a focus on value conflicts.

\section{FBISs - in reports and in the debate}

The work of faith based schools is nowadays regulated by the Swedish School Act that came into force on July $1^{\text {st }} 2011$ (Riksdagen 2010). The overall conditions are given in the introductory paragraphs. In Chapter 1, paragraphs 4 and 5, it is stated that Swedish education shall respect fundamental democratic values and human rights, exemplified by the inviolability of human life, the freedom and integrity of individuals, the equal value of all human beings, gender equality and solidarity between human beings. In paragraph 7, Chapter 1, it is stated regarding independent schools that their education shall not be faith based. Extra-curricular activities can be faith based, but participation in those activities must be voluntary for pupils. Regarding the municipal schools it is stated that both education and extra-curricular activities shall be non-confessional (paragraph 6, Chapter 1). All staff members of all schools are to promote the general value basis (mentioned above). There are other regulations specific for independent schools but being of less importance here. Other changes introduced in the School Act can be seen as responses to discussions during the past decade, e.g. that teachers are 
now only allowed to teach in areas according to their education and not in other curriculum subjects (to stop the use of unqualified teachers). It is also stated that independent schools shall be open to all pupils. Further, local municipal authorities are responsible for all schooling in their area and are to inform themselves about independent schools, due to the supervisory responsibilities of municipal authorities.

What is there then in reports and newspapers concerning FBISs during the period 2010-2012? To respond to this question: a) I have studied the press releases (Swedish: «pressmeddelanden»//«nyheter») issued by SI from July $10^{\text {th }} 2012$ back to January 2011 (as press releases are available for this period); b) I have searched for newspaper clippings in the database Mediearkivet, a full text database of Swedish articles accessible through university libraries, using the keywords «fristående skola» (independent school) and «religion»; c) via the reports and research cited, I have further searched some of the websites of individual FBISs whose names are mentioned; d) focusing on FBISs, I have studied the quality evaluation Mer än vad du kan tro. Religionskunskap i gymnasieskolan (More than you can believe. About religious education in upper secondary school»), a recent report by (SI) (Skolinspektionen 2012a). To summarize: c) and d) have provided the background for the analysis of a) and b) above.

\section{Independent schools in press releases from SI, January 2011 to July 2012}

During the period Jan $1^{\text {st }} 2011$ to July $10^{\text {th }} 2012,300$ press releases have been issued by SI. ${ }^{1}$ Thirty of these can easily be identified as referring to independent schools, either by explicitly mentioning such schools, by mentioning companies, or by mentioning the names of individual independent schools. Almost half (14) of these press releases are of an administrative nature, coming from SI and being on a general level, stating e.g. the increase or decrease in numbers of applications, or announcing that a certain kind of inspection of e.g. companies/business groups will take place. The rest (16) deal with individual independent schools: four decisions regard seven schools that are being closed down, while others direct varying degrees of criticism against certain independent schools, e.g. in one case criticizing a school for requesting financial support from parents, which is not allowed. In a principled article, dated Feb $2^{\text {nd }} 2011$, the head of SI argues for the need for stricter quality control of independent schools. Generally speaking, the reasons behind the closures mentioned above are poor quality, e.g. unqualified teachers, leadership that is insufficiently professional, the school not providing health care, etc. The usual pattern is that, after quality control, these schools have not rectified their internal work and procedures to meet the demands from SI and have then been closed down. In relation to the interest of this study, however, there is no explicit mention of any specific problems relating to FBISs.

\section{Independent schools in the media debate, 2010-2012}

In Mediearkivet, 106 articles were found using the search terms «fristående skol*» (independent school*) and «relig*» for the period 2010 to July $10^{\text {th }} 2012$. The numbers were 40 from 2010, 26 from 2011, and 40 from 2012, however, the time period for 2012 is half a year (until July $10^{\text {th }}$ ). Looking in detail, some of these articles are «cop- 
ies» of each another from different newspapers based on media bulletins from a national news bureau, TT or FLT, or a press release. Further, the proportionally high number for spring 2012 reflects a particularly intense debate regarding municipal schools ending the school year in June at churches. This has long been a tradition in Sweden, where mostly Lutheran churches have been used for this purpose, but the new School Act from 2011 puts this in a different context. Ending the school semester can take place at churches, but with restrictions: one particular hymn can be sung, «Den blomstertid nu kommer», which is a hymn praising the coming summer, describing how life is returning in nature after the winter, a hymn which for long has been used at the ending of school ceremonies. But no other hymns, faith based speeches, or prayers are allowed. This has stirred debate. As this refers to the extra-curricular activities of community-run schools it will be left aside for now, but it should be noted that this is the most debated issue over the studied period and this issue will be brought up in the summary.

Another group of articles that will be left aside are those where the emphasis is on reporting news, e.g. that the Swedish business group, Kunskapsskolan, has established itself by introducing their working methods in a British school (Dagens industri 2010), or regarding matters of local distribution of resources, or changes in upper secondary programs and the influence of this on local schools. The purpose here is to focus on articles where principled arguments are found in relation to issues raised by FBISs. We will now turn to these.

\section{Faith based independent schools - principled debate}

Among the articles within this category, some form part of a discussion by liberals and are found in the liberal newspaper NU, e.g. Hägg (2010) or Haddad (2011). They argue for the neutrality of the state in relation to public funding and the school system. According to them, FBISs can be allowed, but the public funding received needs to be spent on impartial, objective education, i.e. not on faith based education. Hägg and Haddad both argue that extra-curricular activities that are faith based can take place in school, but should not be funded via public funding. Funding for these activities must come via the funding faith communities receive.

Another voice in the principled debate is that of Bo Rothstein, professor of political science, who argues from the point of view of the Swedish constitution against FBISs (Kvällsposten 2011). He takes the criticism against a particular Muslim school in Gothenburg from August 2011 as his starting point, arguing that public Swedish authorities must treat all citizens alike and act out of objectivity and impartiality. As FBISs are publicly funded, this also applies to them. Based on the reported incidents, where pupils seem to have been treated differently, and his assumption that nonMuslim school children are not welcome at the school, Rothstein argues that such a school discriminates, i.e. it does not live up to the demands for equal treatment of all pupils, objectivity and impartiality.

The issue of parents' rights versus the rights of children is discussed by Tomas Englund, professor in education, taking issue with those favoring independent schools 
based on the right of parents to foster their children into their own tradition. Englund argues that the convention of parents' rights to educate their children according to their tradition has primarily been formed to secure the rights of parents under totalitarian regimes denying them this right. Englund denounces the use of this principle to defend FBISs in Sweden. The right of Swedish school children to a diverse education is instead best taken care of at the schools run by communities, i.e. via the public school system (Dagens nyheter 2010).

The issue of parents fostering their children is also commented on by Lars Ohly, the former leader of the leftist party (Swedish: Vänsterpartiet), which is the only Swedish political party to oppose all FBISs. Parents have a right to foster their children into their religion, but this should take place outside school, Ohly argues. The principled standpoint of his party behind this is that of a secular state being open to religious expressions but not enforcing them upon individuals through e.g. FBISs (Kyrkans tidning 2010).

Taking issue with those who naïvely or programmatically favor independent schools, columnist Sakine Madon, in a short commentary, raises the aspects of cultural and socio-economic segregation that independent schools can lead to. Instead of being schools that are rich in diversity, they can be cultural or religious enclaves, and the argument that they contribute toward diversity may not hold true for the pupils attending them (Expressen 2011).

In the debate, expressions are also mirrored from local politicians. Before the 2010 elections, the newspaper Dagen asked all the parliamentary candidates (524) about their view of FBISs in a questionnaire (Dagen 2010). Their opinions vary, with the candidates from the leftist party clearly wanting to ban FBISs, with some of the candidates from the Social Democratic Party and the Green Party also sharing this view, more so than the representatives from the other parties - liberals, conservatives, centrists and Christian Democrats - who do not want to ban these schools at all, or to a lesser extent. The interviewed politicians also express views in line with Madon above, voicing concern for the exposure of children and young people to cultural, religious and socioeconomic diversity (Dagen 2010).

\section{Faith based independent schools - applications and inspections}

Aside from these principled debates, FBISs mainly appear in the media in connection with applications or inspections. For example, a school can be scrutinized regarding its fundamental statutes when it is explicitly Christian, expressing this profile vis-à-vis all activities, including both educational and extra-curricular activities. The extent of the influence of the statutes on the practice is then questioned by SI (Hallands nyheter 2012). Alternatively, a school can be regarded as contributing to segregation through sectarian trends (Hallandsposten 2012). In one inspection, a Christian upper secondary school was criticized for not including enough teaching about Christianity in the curriculum-based part of its education, i.e. for not following the curriculum properly. The school's extra-curricular education featured a considerable proportion of teaching about Christianity, but it was argued that teaching about Christianity in extra-curricular 
activities cannot compensate for deficiencies in the mandatory curriculum (Dagen 2012). In another case, a school did not respond to questions raised by SI, and suspicions of gender discrimination and other forms of discrimination were articulated, resulting in considerable debate (see Kvällsposten 2011). In yet another case, the quality was not at all sufficient to meet the demands from SI, and the school was consequently closed down (Skolinspektionen 2012b).

Going into more detail here and carrying out a detailed study and discussion based on these individual cases would require in-depth research in order to adequately judge these incidents, and would thus go beyond the aim of this article. However, mentioning these individual cases here provides examples of different kinds of problems attracting attention by the authorities. Let us now turn to the summary and discussion of this article.

\section{Summary}

FBISs in Sweden are the second largest group of independent schools after general pedagogical ones, but still far less fewer than those. FBISs educate around one per cent of the pupils in the compulsory school. Between the FBISs they show a great deal of diversity, a few have operated for many years, while others have only recently been founded. There are FBISs of different sizes, some owned by small or larger business groups, and others owned by a foundation or an association. Today, all FBISs are under scrutiny of SI regarding the quality of their education and the controls of SI build on the School Act 2010:800 which came into force in July 2011. Through the controls of SI and the new School Act the conditions for FBISs are clearly defined as compared to a few years back. The criteria for starting and operating a school have now been demarcated and are controlled through inspections, which brings back conditions for a central control of economic resources and their use more in line with the conditions that existed at the beginning of the 1990s. These changes mean that a different situation exists for the actors behind FBISs as compared to when Gerle (1999) made her study.

\section{Freedom of religion - in school}

Addressing now the value conflicts identified by Gerle (1999), it can be seen that the wish to educate one's children in one's own religion through school is expressed in the number of FBISs operating and through applications for the enlargement of existing schools. However, as a result of the new School Act, the possibilities for educating children into a religion are limited to extra-curricular time, although the funding received can be used for these activities too. The School Act here emphasizes a secular rationality as a condition for the curricular activities of the Swedish school system.

\section{Critical thinking - religious truth and authority}

The fostering of critical knowers who form their own opinions through their schooling is not a line of argument that is expressed to any great extent in the debate analyzed 
here. If this issue is broadened in order to connect it more generally to pedagogy, the pedagogical perspectives on the questions seem, in general, to be fairly absent. However, they are touched upon by Englund in his brief article when he argues that a democratic society fosters its pupils in plurality (Dagens nyheter 2010).

\section{Whose rights - those of parents or children?}

One value conflict that comes up again and again in the studied texts is the conflict between the rights of children/young people to an education that serves their own interests and their need for knowledge, versus the rights of parents to decide on the upbringing of their children/young people by fostering them into their religious tradition through school. Both those in favor of FBISs and those against FBISs use their respective arguments in this value conflict.

\section{Individual choice and group/community decision-making - and gender equality}

Gender equality issues are generally very marginal in the media debate, reports and news bulletins. The only article touching upon these is by Rothstein (Kvällsposten 2011). In this particular case, girls seemed to be discriminated against in terms of generally getting lower grades at a certain FBIS. In Gerle's (1999) analysis, the issues of gender are interwoven with cultural issues, expressing a more traditional religious culture where girls and women are subordinated/and or excluded from certain activities. In the texts studied here, these issues have not really come to the fore. Gerle's analysis puts these issues into the context of individualism versus collectivism. Neither of these issues is debated to any significant extent in the studied material.

\section{Underlying value conflict - critical citizens versus devoted religious believers}

The underlying value conflict I identified in Gerle's study dealt with the fostering of critical citizens versus devoted religious believers. These issues are not explicitly expressed as a conflict, but they are mirrored in the discussion by certain liberals who argue against the use of public funding for extra-curricular activities among the FBISs.

\section{New tendencies}

Two more general observations need to be mentioned. In comparison to the issues raised in Gerle's (1999) study, the fear of religious extremism in Christian or Muslim schools that seemed to underlie the debate in the late 1990s appears to have become less now.

Further, Gerle's analysis of the value conflicts in 1999 being positioned in a clash between a Swedish majority society characterized by a secular modernity combined with a cultural homogeneity shaped by centuries of Lutheranism, and cultural and religious minorities challenging this, now seems to be undergoing a change. What I am referring to is the change that has come with the new School Act 2010:800, where the majority society, albeit now seemingly a slightly a different one, has taken a renewed grip on the school system. As a result of the stricter rules for community schools and 
their extra-curricular activities regarding the ending of school ceremonies, i.e. the regulations of religious activities when they take place in religious venues such as Lutheran churches, the centuries of Lutheran influence in schools and an uncritical acceptance of this influence have been challenged. Could this be seen as paving the way for diversity and pluralism in terms of religions and worldviews? Or is it rather an expression of a secular understanding of Swedish education, being fearful of religiosity? Does this change mirror a freedom of or freedom from religious views? It is difficult to give a definitive answer based on this study. More in-depth study is needed.

\section{Discussion}

This study of value conflicts in the debate around faith based independent schools 2010-2012 brought the wider context of the development of independent schools in Sweden into focus, thus we came into contact with a development that has internationally been observed as an extraordinary expansion (Eurydice 2012: 34). A comprehensive school system that included 99 per cent of all pupils has in twenty years been replaced with one where 12-25 per cent of the pupils have their schooling in independent schools. During this same period a supplementary system of setting goals, evaluating and monitoring has been developed through NAE and SI for all schools. Vouchers follow pupils. Individual choice of school is emphasized. The organization of the independent schools as associations, foundations or profit making companies is being researched and debated. Issues of quality of education and segregation through schooling are raised.

In an international perspective educational reforms like these in Sweden are recognizable but they differ between nations as demonstrated in Goodson (2010) where the different historic backgrounds to contemporary shifts in seven European countries have been studied, analyzed and compared. The thorough systemic effects of the present changes of educational systems are analyzed as local but representing global trends by Ball (2009), but also the effects they have on teachers and their professionalism (Ball and Olmedo 2013) is brought up as contemporary changes to former basic educational values. However as the focus here is on FBISs what particular effects are there to be seen from these processes of change in the FBISs?

Well, in the first place it must be stated that the changes has opened for the possibility of starting FBISs, even though a few existed already before the changes started. The possibilities of choice of school also allows for parents to put their children in FBISs. The School Act from 2011 now regulates the freedom of religious education so that the freedom to educate into one's faith has to take place as an extracurricular activity, while the religious education forming part of the curriculum is to be non-confessional and inform about religions, worldviews, ethics and existential questions which is not really different as compared to the curriculum reforms of the 1960s.

When comparing with Gerle's (1999) study the contemporary lessened fear of religious extremism in relation to FBISs might be explained for by the inspection activities of SI. The seemingly diminished interest in issues of gender equality when discussing 
FBISs I find somewhat difficult to explain for given the traditionalism that can be found in religious contexts, but on the other hand when transgressions take place and girls are discriminated against voices are raised. From a pedagogical point of view it is further of interest that so little attention is given to the fostering of critical citizens and what that takes both within the FBISs and in general. The value conflict in the comparison that is most debated in the studied material is the one of parent's versus children's rights when it comes to fostering into a religious tradition or freedom from that $-\mathrm{a}$ seemingly perennial issue from a rights point of view.

Why then do FBISs exist given that they have a fairly circumscribed freedom of action in Sweden today? In Jackson (2003) he among other arguments highlighted that a strong motivation behind faith based independent schools in England and Wales is a special ethos connected to the values and moral views embodied in a religion or worldview. Whether this is a reason behind the strong interest in FBISs in Sweden cannot be answered by this study but their increase in numbers might be interpreted to point in that direction.

Commenting here lastly on the vast changes of the educational Swedish system that the expansion of FBISs is forming a minor part of, I would as I summarize this study and comparison with Gerle's study note, that the all overshadowing value conflict found in reports and materials today concern the issue of whether profit that is made in grant-funded Swedish independent schools can be used for other purposes than reinvestment in the actual school. This is a new and rising value conflict.

\section{Notes}

1 Available from: http://www.skolinspektionen.se/sv/Nyheter---samlade/

\section{References}

Arreman, Inger Erixon and Ann-Sofie Holm 2011. Privatisation of public education? The emergence of independent upper secondary schools in Sweden. Journal of Education Policy 26(2): 225-243.

Ball, Stephen J. 2009. Privatising education, privatizing education policy, privatizing educational research: network governance and the 'competition state'. Journal of Educational Policy 24(1): 83-99.

Ball, Stephen J. and Antonio Olmedo 2013. Care of the self, resistance and subjectivity under neoliberal governmentalities. Critical Studies in Education 54(1): 85-96.

Berge, Øyvind and Christer Hyggen 2011. Privatskoler i Norden. Omfang, utvikling og den politiske debatten (Private schools in the Nordic countries. Extension, development and the political debate). Oslo: Fafo.

Böhlmark, Anders and Mikael Lindahl 2008. Does School Privatization Improve Educational Achievement? Evidence from Sweden's Voucher Reform. Bonn: Discussion Paper Series No. 3691, Institute for the Study of Labor (IZA).

Dagen 2010. Fortsatt tydligt stöd för konfessionella friskolor (Continued evident support for confession based independent schools), 8 September. 
Dagen 2012. Inte tillräckligt med kristendom (Not enough Christianity), 4 April.

Dagens industri 2010. Svensk friskola i brittisk valdebatt (Swedish independent school in British election debate), 7 April.

Dagens nyheter 2010. Skam för en demokrati (Shame for a democracy), 19 March.

Daun, Holger 2008. Islam, Christianity and Secularism in European Education. Policy Futures in Education 6(6): 730-743.

Eurydice 2012. Key Data on Education in Europe 2012. Brussels: Education, Audiovisual and Culture Executive Agency.

Expressen 2011. Skilda skolor (Separate schools), 20 August.

Gerle, Elisabeth 1999. Mångkulturalism - för vem? Debatten om muslimska och kristna friskolor blottlägger värdekonflikter $i$ det svenska samhället (Multiculturalism - for whom? The debate on Muslim and Christian independent schools reveals value conflicts in Swedish society). Nora: Bokförlaget Nya Doxa.

Goodson, Ivor F. 2010. Times of educational change: towards an understanding of patterns of historical and cultural refraction. Journal of Educational Policy 25(6): 767-775.

Haddad, Roger 2011. Religion får man välja på fritiden (Religion may be chosen in free time). NU, No.39:20.

Hallandsposten 2012. Laboraskolan anmäls till Skolinspektionen (Labora school reported to the School Inspectorate), 28 April.

Hallands nyheter 2012. Skolinspektionen vill stoppa Leteboskolan (The School Inspectorate wants to stop Leteboskolan), 6 July.

Hägg, Ingemund 2010. Gör religiösa friskolor mer liberala (Make faith based independent schools more liberal). $N U$, No.3:19.

Jackson, Robert 2003. Should the State Fund Faith Based Schools? A Review of the Arguments. British Journal of Religious Education 25(2): 89-102.

Kyrkans tidning 2010. Lars Ohly: Vi vill utjämna skillnaderna mellan människor (Lars Ohly: We want to even out the differences between people), 22 July.

Kvällsposten 2011. Religiösa friskolor strider mot lagen (Faith based independent schools are against the law), 9 August.

Lundahl, Lisbeth 2002. Sweden: decentralization, deregulation, quasi-markets - and then what? Journal of Education Policy 17(6): 687-697.

Regeringen 2011. Kommittédirektiv. Regler och villkor för fristående skolor m.m. (Directions for committee work. Rules and regulations for independent schools etc.). Stockholm: Utbildningsdepartementet. Available from: http://www.regeringen.se/sb/d/14106/a/172724 [Accessed 5 July 2012].

Riksdagen 2010. Skollag 2010:800 (School Act). Stockholm: Utbildningsdepartmentet. Available from: http://www.riksdagen.se/sv/Dokument-Lagar/Lagar/Svenskforfattningssamling/ Skollag-2010800_sfs-2010-800/?bet=2010:800\#K2 [Accessed 6 July 2012].

Rönnberg, Linda, Joakim Lindgren, and Christina Segerholm 2013. In the public eye: Swedish school inspection and local newspapers: exploring the audit-media relationship. Journal of Educational Policy 28(2): 178-197.

Skolinspektionen 2012a. Mer än vad du kan tro. Religionskunskap i gymnasieskolan. Kvalitetsgranskning (More than you can believe. Religious education in upper secondary school. Quality review). Rapport 2012:3. Stockholm: Skolverket. Available from: http://www.skolinspektionen.se/Documents/Kvalitetsgranskning/rela/kvalgr-rela-slutrapport.pdf [Accessed 7 June 2012]. 
Skolinspektionen 2012b. Fristående grundskola i Stockholm stängs (Independent school in Stockholm closed down). Available from: http:/www.skolinspektionen.se/sv/Om-oss/ Press/Pressmeddelanden/Fristaende-grundskola-i-Stockholm-stangs/. [Accessed 15 July 2012].

Skolverket 1997. Barn mellan arv och framtid. Konfessionella, etniska och språkligt inriktade skolor $i$ ett segregationsperspektiv (Children between heritage and future. Confessional, ethnic and language oriented schools from a perspective of segregation). Stockholm: Skolverket.

Skolverket 2008. Privat och offentligt. Fristående skolor i andra länder (Private and public. Independent schools in other countries). Stockholm: Skolverket.

Skolverket 2011a. Skolverkets lägesbedömning 2011. Del 1 - Beskrivande data (The current situation of the Swedish school. Part 1 - Descriptive data). Stockholm: Skolverket.

Skolverket 2011b. Skolverkets lägesbedömning 2011. Del 2 - Bedömningar och slutsatser (The current situation of the Swedish school. Part 2 - Evaluations and conclusions). Stockholm: Skolverket.

Skolverket 2012a. Enskilda huvudmän och skolmarknadens ägarstrukturer (Independent education providers and the owner structures of the school market). Skolverkets aktuella analyser 2012. Stockholm: Skolverket.

Skolverket 2012b. En bild av skolmarknaden. Syntes av Skolverkets skolmarknadsprojekt (A picture of the school market. A synthesis of the SNAE's school market project). Stockholm: Skolverket.

Vlachos, Jonas 2010. Betygets värde. En analys av hur konkurrens påverkar betygsättningen vid svenska skolor (The value of grades. An analysis of how competition influences grading in Swedish schools). Stockholm: Konkurrensverket/Swedish Competition Authority. 